DOI: 10.17707/AgricultForest.63.3.11

\author{
Miljan VELJIĆ, Dušica RADONJIĆ, Milena ĐOKIĆ
}

\title{
EFFECT OF LIGHTING PERIOD AND DIETS DENSITY OF BROILES ON THE APPEARANCE OF LESIONS ON THE FOOT PADS
}

\section{SUMMARY}

The experiment involved 320 chickens of the line Cobb 500, both sexes, a cycle lasted 42 days. The floor area was covered with $10 \mathrm{~cm}$ of sawdust.

The factors in this experiment were: 1) lighting program (constant light CL, declining light - DL and then growing light -GL; and 2) density of diets at a constant energy-protein ratio (mixture of lower energy and protein - LEP and mixtures with a higher content of energy and protein - HEP).

The chickens were divided into four groups in the form of two-factorial trial randomized block design (2x2) - four repetitions with 20 birds per repetition.

Chickens in control group „LE" were fed with standard starter and grower mixtures. Chickens in „HEP" were fed with standard mixtures with addition of oil and soybean meal.

Assessment of damage and the presence of lesions in all experiments were carried out on 21st, 28th, 35th and 42nd day of the cycle. Condition of foot pads of all chickens was assessed by three-step method for assessing dermatitis (Tomas et al. 2004). The applied lighting programs and diets density had no effect on the appearance of lesions on the foot pads.

Keywords: broilers, lighting period, diets density, lesions of the foot pads

\section{INTRODUCTION}

In order to determine the level of animal welfare for chicken, in addition to other parameters, the assessment of the condition and appearance of lesions on foot pads, hocks and chest is used. These three parameters represent an indication of accommodation condition, general welfare of chicken and production systems in Europe and the United States (Berg, 2004; Berg and Algers, 2004;). Lesions of the hock and chest indicate bad conditions of keeping and movement of chickens. Poultry with difficult foot pads damages has a reduced growth because reduced food intake, which is due to pain that occurs during moving (Martland, 1984, 1985). Different lighting programs lead to changes in the behavior and physical activity of broilers, and thus affect the welfare of the individuals (Škrbić et al. 2009). Different lighting programs can be used to reduce damage on the pads. Thus, Van Harn (2009) compared the influence of two light modes (constants and alternating) on appearance of damage to the pads. The results of this study have shown that alternating light regime significantly reduces occurrence the

\footnotetext{
${ }^{1}$ Miljan Veljić (corresponding author: miljan11@hotmail.com), Dušica Radonjć, Đokić Milena, University of Montenegro, Biotechnical faculty, Podgorica, MONTENEGRO.

Notes: The authors declare that they have no conflicts of interest. Authorship Form signed online.
} 
lesions on foot pads. The author explained this result by increasing activity of chicken when the light is on, resulting in a greater degree disperse of sawdust.

Increased physical activity of the chicken caused by regular changing of light and darkness in alternating lighting program and total duration of the photoperiod of 16 hours leads to an improvement in resistance broiler legs and the reduction of problems with the formation of foot lesions (Škrbić et al., 2009).

Studding the effects of two light programs: a) continuously reduced photoperiod 18L: 6D and b) "step by step" program- gradual extension of the light period after the start of the restriction 16L: 8D, Škrbic et al. (2014) found greater presence of lesions on broiler foot pads at the first than in the second program, and differences were statistically significant.

The higher frequency of severe lesions on foot pads in continuous light program compared to the intermittent light program was determined by Petek i sar. (2010). Unlike the above research, Sirri et al. (2007) did not determine the effects of light on the appearance of lesions on foot pads.

Schwean-Lardner et al. (2013) examined how four light programs with a photoperiod of 14, 17, 20 and 23 hours influenced mortality, foot and eye health. In the 28-day-old chickens, there was no difference between researched light program in terms of the frequency of dermatitis on the foot pads, but the average score was greater and statistically significant in the conditions of prolonged photoperiod. At the age of 35 days, the higher frequency of chickens without lesions (grade 0) was determined at the length of photoperiod from 14 and 17 hours, compared to 20 and 23 hours. Also, the average grade of dermatitis was higher in chickens raring at longer photoperiods. In the age of 49 days, was not determined the effect of light programs on frequency, nor on average assessment of dermatitis on the foot pads.

Feed can influence on damage the foot pads over the quality of the sawdust. The quality sawdust is influenced by ratio of energy / protein, the crude protein content, the ratio of amino acids, the content of crude fats, the type of fat and the balance of electrolytes (Veldkamp and Van Harn, 2009). Except effects of feed on the damages foot pads over the quality of sawdust, it has been shown that the occurrence or absence of certain nutrients is affected by the appearance of the damage (Youssef et al., 2012; Abd El-Wahab et al., 2013).

Škrbić et al. (2014) examined the influence of standard and economical mixture on the occurrence of lesions on the foot pads. The mixes differed in the content of raw fat about $1 \%$, the content of raw cellulose by about $0.5 \%$ and slightly higher content of total phosphorus in the starter and grover standard mixture, than to the corresponding economic mix. The authors found a significantly higher percentage of difficult lesions in chickens fed by economic mixtures as a result of the increased moisture content of the sawdust due to poor digestibility and nutritional value of the economic mixture, which affected the viscosity of digest which reduced water absorption and increased water loss by excretion. 
A high level of crude protein has a negative effect on the quality of the sawdust, as confirmed by the results of Ferguson et al. (1998) which show that content of moisture has increased with increasing protein content in the mixtures.

A high level of crude protein leads to greater formation of uric acid in the liver and its renal excretion (De Jong et al., 2010, 2015), which results in poor quality the sawdust and increases the risk of formation the lesions on foot pads. Shepherd and Fairchild (2010) show that diet with unbalanced mixtures in terms of crude protein has the same effect.

Bilgili et al. (2005), in research with 4 different nutritional programs (different concentrations of nutrients in the meal), showed that concentration of nutrients in the meal significantly influenced appearance of lesions on foot pads. To the same conclusion came Bilgili i sar. (2006) researching effect of mixtures with different levels of protein and metabolic energy on the occurrence of lesion foot pads of broiler. They compared the starter and gover mixture with an increased amount of proteins (starter: 21 and 21.5\%, grover: 19.76 and 20\%) and energy (starter: 3109 and $3193 \mathrm{kcal}$; grover: 3158 and $3226 \mathrm{kcal}$ ). Assessment of the presence and size of lesions on the pads was performed on 35, 42, 49 and 56 days. The results of comparison two types of mixtures at all researched ages showed statistically significantly higher percentage of broilers without lesions when feeding with mixtures with lower levels of proteins and energy.

The aim of this research was to determine the effect of a light program and density meal on the occurrence of lesions on foot pads.

\section{MATERIALS AND METHODS}

In research was involved total of 320 chickens of line-shaped hybrid Cobb 500 , mixed sex, and research lasted for 42 days. The floor area of the stall was covered with sawdust thickness of $10 \mathrm{~cm}$.

The factors in this experiment were: 1) lighting program (constant light CL, declining light - DL and then growing light -GL; and 2) density of diets at a constant energy-protein ratio (mixture of lower energy and protein - LEP and mixtures with a higher content of energy and protein - HEP).

The chickens were divided into four groups in the form of two-factorial trial randomized block design (2x2) - four repetitions with 20 birds per repetition: a) chickens fattened in a constant light (CL) and a lower diets density (LEP); b) chickens fattened in a constant light (CL) and higher diets density (HEP); c) chickens fattened in declining-growing light (DGL) and a lower diets density (LEP); d) chickens fattened in declining-growing light (DGL) and higher diets density (HEP).

Chickens in all four groups in the first week were raised on 23 hours of light and 1 hour of darkness.

From the second week to the end of fatting period, chickens in groups a and $b$ were exposed to the CL light program of 18L: 6D, while the chickens in the groups $\mathrm{c}$ and $\mathrm{d}$ were exposed to the GL light program, as follows: from the 
second week 12L: 12D; third 1LS; 10D; fourth 16L: 8D: fifth 18L: 6D and sixth 20L: 4D.

The floor area was covered with $10 \mathrm{~cm}$ of sawdust. The population density was 17 chickens per $\mathrm{m}^{2}$. Chickens in control group „LE" were fed with standard mixtures.

The starter mixture with which the chickens were feeding from the first to 14 days contained 12,30 MJ / $\mathrm{kg} \mathrm{ME}$ and 21,22\% SP and a ratio E / SP 138; grover mixture contained 12.49 MJ / kg ME and 20.19\% SP with E / SP ratio of 147 and finisher with 12.69 MJ / kg ME and 18.64 SP with E / SP ratio of 162.

Chickens in „HEP" were fed with standard mixtures with addition of oil and soybean meal. The starter mixture with wich the chickens were feeding from the first to 14 days contained $12.76 \mathrm{MJ} / \mathrm{kg} \mathrm{ME}$ and $22.04 \% \mathrm{SP}$ and a ratio E / SP 138; Grover mixture contained 12.98 MJ / kg ME and 20.98\% SP with an E / SP ratio of 147 and a finisher with 13.22 MJ / kg ME and 19.39 SP with an E / SP ratio of 162.

Assessment of damage and the presence of lesions in all experiments were carried out on $21^{\text {st }}, 28^{\text {th }}, 35^{\text {th }}$ and $42^{\text {nd }}$ day of the cycle. Condition of foot pads of all chickens was assessed by three-step method for assessing dermatitis (Tomas et al. 2004), with marks 1,2,3.

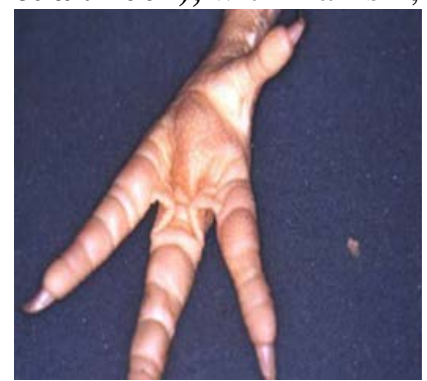

Mark 1

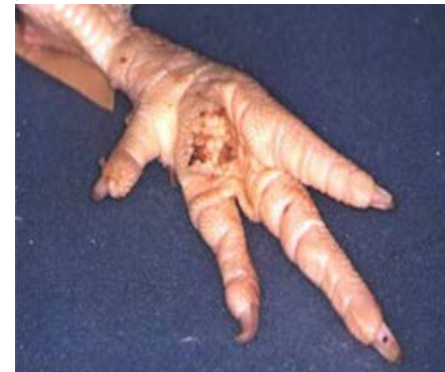

Mark 2

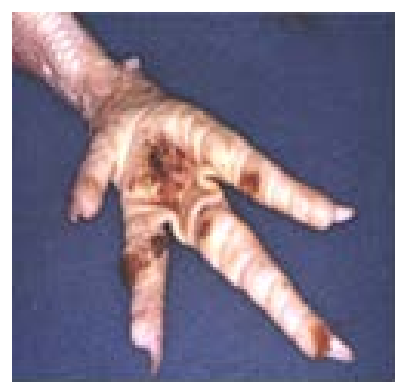

Mark 3

Figure 1. Photo of food pads with estimates in accordance with the applied assessment methodology (Tomas et al 2004)

Exist differences in criterion: mark 1- refers to foot pads without lesions (lesions not exist or with very little surface damage, slight change in color of the restricted area of the foot); mark 2 is assigned for mediumheavy lesions (mild damage, changes in the color of the foot skin, surface damage, dark papillae and thickening) and mark 3 for severe lesions (significant damage, epidermis is affected, the existence of ulcers, there are signs of bleeding or overdoze of foot pad) as shown in the pictures.

The data were processed by the computer program STATISTICA 6. Mean values and variation measures were determined. An analysis of variance (ANOVA) was done, and in the case of statistical significance in the analysis of variance, the LSD test at the level at significance level of $5 \%$ and $1 \%$ was applied. 


\section{RESULTS AND DISCUSSION}

Effects of light and density of population on frequency of lesions on foot pads with marks: 1 - no lesions; 2 - the appearance of mild lesions and the 3 severe form of lesions in the third, fourth, fifth and sixth week of chick age are shown in Tables 1, 2, 3 and 4.

Table1. Average grade and frequency of occurrence (\%) lesions on foot pads at 21 day old chickens

\begin{tabular}{|c|c|c|c|c|c|c|}
\hline \multirow{2}{*}{ Treatments } & \multirow{2}{*}{ Factors level } & \multicolumn{4}{|c|}{ Frequency } & Average \\
\cline { 4 - 6 } & & Grade 1 & Grade 2 & Grade 3 & \\
\hline \multirow{2}{*}{ Light program } & CL & $\bar{X}_{ \pm} S d$ & $85,97 \pm 2,40$ & $14,03 \pm 2,40$ & $0,00 \pm 0,00$ & $1,15 \pm 0,37$ \\
\cline { 2 - 6 } & DLP & $\bar{X}_{ \pm} S d$ & $83,41 \pm 6,00$ & $12,78 \pm 4,75$ & $3,81 \pm 3,57$ & $1,20 \pm 0,49$ \\
\hline \multirow{2}{*}{ Density of diets } & LEP & $\bar{X}_{ \pm} S d$ & $86,74 \pm 5,22$ & $12,01 \pm 4,52$ & $1,25 \pm 2,31$ & $1,14 \pm 0,38$ \\
\cline { 2 - 6 } & HEP & $\bar{X}_{ \pm} S d$ & $82,64 \pm 2,94$ & $14,79 \pm 2,08$ & $2,57 \pm 4,46$ & $1,21 \pm 0,48$ \\
\hline LP & & & Ns & ns & Ns & ns \\
\hline DD & & & Ns & ns & Ns & ns \\
\hline
\end{tabular}

CL - constant light (I week 23L:1D; form II to VI weeks 18L:6D);

DLP- decrising - incrising light program (I week 23L:1D; II nedelja12L:12D; III weeks 14L:10D; IV week 16L:8D; V week 18L:6D and VI weeks 20L:4D HEP- high energy and protein content. LEP- low energy and protein content; ns - nonsignificant differences $\mathrm{p}>0.05$;

There were no differences between chickens raised at CL and on DLP, on incidence rate (\%) of the lesions and at the average grade in any test period. Our results are in agreement with the results of Sirri and sar. (2007), which also did not determine the impact of a light program on the appearance of lesions on the foot pads. Contrary to these studies, Van Harn (2009) found that the alternating light program significantly reduced the occurrence of lesions of food pads compared to the constant light program, and this is explained by the increased activity of the chickens during the period turn light, resulting in a greater disperse sawdust. The higher incidence of severe lesions on foot pads in the continuous light compared to the intermittent light program was determined by Petek i sar. (2010), while Škrbić et al. (2014) determined a higher presence of lesion on foot pads at a constant-reduced photoperiod (18L: 6D) compared to step-by-step program gradually extending the light period after the start of the restriction 16S: $8 \mathrm{M}$.

The differences between the groups of chickens fed with LE and HEP are not statistically significant ( $\mathrm{P}>0.05$ ) on appearance of lesions on foot pads of the 21st, 28th, 35th and 42nd days. (Tables 1, 2, 3 and 4).

However, in all study periods, the tendency of reducing difficult forms of lesions was observed (mark 3) in chickens which were fed with lower protein and energy content compared to the group which were fed with higher contents of protein and energy. 
Table 2. Average grade and frequency of occurrence (\%) lesions on foot pads at 28 day old chickens

\begin{tabular}{|c|c|c|c|c|c|c|}
\hline \multirow{2}{*}{ Treatments } & \multirow{2}{*}{\multicolumn{2}{|c|}{ Factors level }} & \multicolumn{3}{|c|}{ Frequency } & \multirow{2}{*}{$\begin{array}{c}\text { Average } \\
\text { grade }\end{array}$} \\
\hline & & & Grade 1 & Grade 2 & Grade 3 & \\
\hline \multirow{2}{*}{$\begin{array}{c}\text { Light } \\
\text { program }\end{array}$} & CL & $\bar{X}_{ \pm S d}$ & $73,34 \pm 6,56$ & $20,31 \pm 6,30$ & $6,35 \pm 4,40$ & $1,33 \pm 0,59$ \\
\hline & DLP & $\bar{X}_{ \pm S d}$ & $72,65 \pm 4,34$ & $19,61 \pm 6,79$ & $7,74 \pm 4,25$ & $1,36 \pm 0,62$ \\
\hline \multirow{2}{*}{$\begin{array}{l}\text { Density of } \\
\text { diets }\end{array}$} & LE & $\bar{X}_{ \pm S d}$ & $74,67 \pm 4,75$ & 19,01 & $6,32 \pm 4,41$ & $1,32 \pm 0,59$ \\
\hline & HEP & $\bar{X}_{ \pm S d}$ & $71,32 \pm 5,76$ & $20,90 \pm 7,91$ & $7,78 \pm 4,22$ & $1,37 \pm 0,63$ \\
\hline LP & & & ns & ns & ns & ns \\
\hline DD & & & ns & ns & ns & ns \\
\hline
\end{tabular}

CL - constant light (I week 23L:1D; form II to VI weeks 18L:6D);

DLP- decrising - incrising light program (I week 23L:1D; II nedelja12L:12D; III weeks 14L:10D; IV week 16L:8D; V week 18L:6D and VI weeks 20L:4D HEP- high energy and protein content. LEP- low energy and protein content; ns - nonsignificant differences $\mathrm{p}>0.05$;

Table 3. Average grade and frequency of occurrence (\%) lesions on foot pads at 35 day old chickens

\begin{tabular}{|c|c|c|c|c|c|c|}
\hline \multirow{2}{*}{ Treatments } & \multirow{2}{*}{\multicolumn{2}{|c|}{ Factors level }} & \multicolumn{3}{|c|}{ Frequency } & \multirow{3}{*}{$\begin{array}{c}\begin{array}{c}\text { Average } \\
\text { grade }\end{array} \\
1,49 \pm 0,70\end{array}$} \\
\hline & & & Grade 1 & Grade 2 & Grade 3 & \\
\hline \multirow{2}{*}{$\begin{array}{c}\text { Light } \\
\text { program }\end{array}$} & $\mathrm{CL}$ & $\bar{X}_{ \pm} S d$ & $62,80 \pm 3,45$ & $24,99 \pm 5,60$ & $12,21 \pm 4,77$ & \\
\hline & DLP & $\bar{X}_{ \pm S d}$ & $62,72 \pm 5,87$ & $25,49 \pm 4,26$ & $11,80 \pm 3,80$ & $1.49 \pm 0,70$ \\
\hline \multirow{2}{*}{$\begin{array}{l}\text { Density of } \\
\text { diets }\end{array}$} & LEP & $\bar{X}_{ \pm S d}$ & $63,16 \pm 5,60$ & $25,20 \pm 5,34$ & $11,65 \pm 4,73$ & $1,48 \pm 0,70$ \\
\hline & HEP & $\bar{X}_{ \pm S d}$ & $62,36 \pm 3,82$ & $25,28 \pm 4,59$ & $12,36 \pm 3,82$ & $1,50 \pm 0,71$ \\
\hline LP & & & ns & ns & ns & ns \\
\hline DD & & & ns & ns & ns & ns \\
\hline
\end{tabular}

CL - constant light (I week 23L:1D; form II to VI weeks 18L:6D);

DLP- decrising - incrising light program (I week 23L:1D; II nedelja12L:12D; III weeks 14L:10D; IV week 16L:8D; V week 18L:6D and VI weeks 20L:4D HEP- high energy and protein content. LEP- low energy and protein content; ns - nonsignificant differences $\mathrm{p}>0.05$;

Results of Ferguson et al. (1998) indicate that the increase in protein content in the mixtures resulted an increase moisture content in the sawdust, which caused a greater frequency of the lesions on foot pads.

High level of crude protein leads to a greater formation of uric acid in the liver and its renal excretion (De Jong et al., 2010), which results in poor quality the sawdust and increases the risk of the formation of the lesions on foot pads. Biligili i sar. (2006) found that chickens which were fed at higher energy levels had a higher percentage of lesions on foot pads of the 35th, 42nd, 49th, and 56th days compared to those fed with a lower level of energy. In the research of De Yong et al. (2015), the opposite was found - the higher frequency of lesion on foot pads in chickens which were fed with lower than higher level of energy, 
which, according to the authors, is the result of higher moisture content in sawdust in group of chickens fed with rations with lower levels of energy.

Table 4. Average grade and frequency of occurrence (\%) lesions on foot pads at 42 day old chickens

\begin{tabular}{|c|c|c|c|c|c|c|}
\hline \multirow{2}{*}{ Treatments } & \multirow{2}{*}{ Factors level } & \multicolumn{4}{|c|}{ Frequency } & Average \\
\cline { 3 - 6 } & grade \\
\hline $\begin{array}{c}\text { Light } \\
\text { program }\end{array}$ & CL & $\bar{X}_{ \pm} S d$ & $57,01 \pm 6,62$ & $28,83 \pm 7,03$ & $14,16 \pm 4,69$ & $1,57 \pm 0,73$ \\
\cline { 2 - 6 } & DLP & $\bar{X}_{ \pm} S d$ & $57,91 \pm 6,06$ & $26,97 \pm 5,80$ & $15,12 \pm 3,17$ & $1,57 \pm 0,74$ \\
\hline \multirow{2}{*}{$\begin{array}{c}\text { Density of } \\
\text { diets }\end{array}$} & LEP & $\bar{X}_{ \pm} S d$ & $58,62 \pm 6,73$ & $27,76 \pm 6,84$ & $13,62 \pm 4,11$ & $1,55 \pm 0,72$ \\
\cline { 2 - 6 } & HEP & $\bar{X}_{ \pm} S d$ & $56,30 \pm 5,72$ & $28,05 \pm 6,18$ & $15,66 \pm 3,64$ & $1,59 \pm 0,75$ \\
\hline LP & & & ns & ns & Ns & ns \\
\hline DD & & & ns & ns & Ns & ns \\
\hline
\end{tabular}

CL - constant light (I week 23L:1D; form II to VI weeks 18L:6D);

DLP- decrising - incrising light program (I week 23L:1D; II nedelja12L:12D; III weeks 14L:10D; IV week 16L:8D; V week 18L:6D and VI weeks 20L:4D HEP- high energy and protein content. LEP- low energy and protein content; ns - nonsignificant differences $\mathrm{p}>0.05$;

\section{CONCLUSION}

Influence of the duration of light programs and density of diets on the occurrence of lesions on foot pads was not statistically significant $(\mathrm{P}>0.05)$, even in one examination period.

However, in all study periods, the tendency of reducing difficult forms of lesions (mark 3) was observed in chickens which were fed with lower content of protein and energy compared to group fed with higher contents of protein and energy.

\section{REFERENCES}

Abd El-Wahab, A., Radko, D. and Kamphues, J. (2013). High dietary levels of biotin and zinc to improve health of foot pads in broilers exposed experimentally to litter with critical moisture content. Poult. Sci. 92: 1774-1782

Berg, C. (2004). Pododermatitis and hock burn in broiler chickens, in: WEEKS, C.A. \& BUTTERWORTH, A. (Eds) Measuring and Auditing Broiler Welfare, pp. 37-49 (Wallingford, United Kingdom, CABI Publishing).

Berg, C. and Algers, B. (2004). Using welfare outcomes to control intensification: The Swedish model. Pages 223-229 in Measuring and Auditing Broiler Welfare. C. A. Weeks and A. Butterworth, ed. CABI Publishing, Wallingford, UK.

Bilgili S.F., Alley M.A., Hess J.V. and M. Nagaraj ( 2006): Influence of Age and Sex on Footpad Quality and Yield in Broiler Chickens Reared on Low and High Densiti Diets. Journal of Applies Poultry Research, 15: 433 - 441

Bilgili, S. F., Alley, M. A., Hess, J. B. and Moran, E. T. (2005). Influence of strain-cross, sex and feeding programs on broiler chicken paw (feet) yield and quality. XVII European Symp. on Quality of Poultry Meat, Doorwerth, The Netherlands Pages 342-349 in Proc.

De Jong, I.C., Veldkamp, T. and Van Harn, J. (2010). Management tools to reduce footpad dermatitis in broiler chickens. Proceedings of the 19th European Symposium on Poultry Nutrition, Potsdam, Germany, 26-29 August 2013. p. 78 - 83 
De Jong, Ingrid C , Lourens, A.and van Harn.J. (2015):Effect of hatch location and diet density on footpad dermatitis and growth performance in broiler chickens.J. Appl. Poult. Res. 24:105114

Ferguson, N. S., Gates, R. S., Taraba, J. L., Cantor, A. H., Pescatore, A. J., Ford, M. J. and Burnham, D. J. (1998). The effect of dietary crude protein on growth, ammonia concentration, and litter composition in broilers. Poult. Sci. 77:1481-1487

Martland, M. F. (1984). Wet litter as a cause of plantar pododermatitis, leading to foot ulceration and lameness in fattening turkeys. Avian Pathol. 13:241-252.

Martland, M. F. (1985). Ulcerative dermatitis in broiler chickens: The effects of wet litter. Avian Pathol. 14:353-364.

PetekMetin,Cibik Recep, Yildiz Huseyin, Sonat AkFisun, Gezen Sule Serife, Orman Adbulkadir, Aydin Cenk. (2010):The influence of different lighting programs, stocking densities and litter amounts on the welfare and producitivity traits of a commercial broiler line. Veterinarija in zootechnika 51(73)

SCHWEAN-LARDNER K., FANCHERB. I.,GOMISS.,VAN KESSELA.,DALAL S.,CLASSEN H.L.(2013):Effectof day lenght on cause of mortality ,leg health,and ocular health in broilers.Poultry Science,92:1-11

Shepherd E. M. and Fairchild B. D. (2010): Footpad dermatitis in poultry. Poultry Science 89 :2043-2051 doi: 10.3382/ps.2010-00770

Siri F., Minelli G., Folegatti E., Lolli S., Meluzzi A. (2007): Foot dermatitis and productive traits in broiler chickens kept with different stocking densities, litter types and light regimen. Ital. J. Anim, Sci. Vol.6 (suppl.1),734-736 